\title{
HEIGHTS AND WEIGHTS OF BARBADIAN SCHOOL CHILDREN
}

\author{
BY \\ K. L. STANDARD* \\ Department of Social and Preventive Medicine \\ and \\ M.R.C. Epidemiological Research Unit, University of West Indies, Jamaica \\ H. G. LOVELL \\ M.R.C. Epidemiological Research Unit, University of West Indies \\ AND \\ LENORE HARNEY \\ Medical Officer of Health, Barbados, West Indies
}

The size of school children is a valuable index of the wellbeing of a community. The effects on the general level of health of different environments, of long-term changes in standards of living, and of other features of sections of a community are often reflected in the growth of children. Thus a knowledge of heights and weights may aid an assessment of effects of infectious disease, diet, and race.

No comprehensive anthropometric data for Barbadian school children have previously been published, although Standard (1964) gave mean heights and weights for children under 7 years of age. The figures here reported cannot, therefore, be used to evaluate past changes but, particularly since this survey coincided with the introduction of a school meals programme, they may be useful in providing a baseline for future studies of secular change in the growth of school children. They also make possible comparisons with other Caribbean Islands for which data have recently been published (Ashcroft and Lovell 1966a; Ashcroft, Buchanan, and Lovell 1965).

Barbados is the most easterly of the Caribbean Islands, being situated at about latitude $13^{\circ}$ north and longitude $60^{\circ}$ west. The island covers 166 square miles and is of coral formation, except for a small part in the north-east which is volcanic. It is hilly rather than mountainous, the land rising in gentle terraces to a ridge near the centre of the island, which reaches just over 1,100 feet. The north-east has hills which descend steeply to the sea. The climate is tropical. Extreme temperatures are

- Formerly Medical Officer of Health, Barbados, West Indies. $63^{\circ} \mathrm{F}$. and $88^{\circ} \mathrm{F}$., with a mean of about $78^{\circ} \mathrm{F}$., and average rainfall is about 60 inches.

The population of Barbados as given by the 1960 census was approximately 232,000. Population density, measured as the number of persons per square mile, is 1,400 in Barbados. A more meaningful figure for the islands of the West Indies is the number of persons per acre of cultivable land, as used by O'Loughlin (1960). By this standard, Barbados has twice as many people per acre of cultivable land as Trinidad, three times as many as Jamaica, and six times as many as Dominica. The economy of Barbados is based chiefly on the sugar industry. The "crop" season (when sugar-cane is harvested and sugar is made at the factories) usually lasts 4 to 5 months, from January to May. During this period there is nearly full employment and more money is in circulation. In the "out-of-crop" season there is both underemployment and unemployment.

There is a government health centre in each of three local government areas: Bridgetown, which has a population of 100,000 , the Northern district, and the Southern district. Child health clinics are held weekly at these centres and their sub-stations as well as at some voluntary clinics. There is no specially organized nutrition programme as yet. There is a free dental service employing three dentists part-time for persons attending antenatal clinics and for school children up to 14 years, but the programme is confined to extractions. Preventive dentistry is available only by personal arrangement with the dentist to whom a fee is paid by the individual.

The birth rate in 1962 was 29.6 and the death rate $9 \cdot 1$ per thousand. The infant mortality rate has 
been declining steadily, from 135 per 1,000 live births in 1955 to 52 in 1964 . Child mortality for the age group 1 to 4 years is low and compares favourably with economically advanced countries (Standard, 1961). Mantoux tests and BCG vaccinations are given to all children in government schools, on entry and on leaving. The death rate from tuberculosis for 1965 was $2 \cdot 5$ per 100,000 . There has been no malaria in Barbados for at least 30 years. In a survey for ova and cysts in stool specimens carried out on 500 school children aged 5 and 6 years in seventeen government schools in the southern area of Barbados in 1961, one of the authors (K.L.S.) found that the infestation rate for Ascaris lumbricoides (round worm) was 13.6 per cent and for Trichuris trichiura (whip worm) $25 \cdot 8$ per cent. No hookworm was found.

\section{Method OF INVESTIGATION}

The sample was taken from government schools all over the island which, for the purpose, was divided into five areas (Fig. 1):
North coastal area (St. Lucy and St. Peter)

Hilly area (St. Andrew and St. Joseph)

Inland area

(St. George, St. Thomas, St. John, and St. James)

City area

(St. Michael)

South-east coastal area (Christ Church and St. Philip)

The ages of the children ranged from 5 to 14 years and an effort was made to study approximately 100 boys and 100 girls in each age group in each area. Altogether 9,232 children were weighed and measured, 4,664 boys and 4,568 girls.

The children were weighed on a balance which incorporated a horizontal rod sliding on a vertical scale for measuring heights. Weights were recorded to the nearest $\frac{1}{2}$ pound below and heights to the nearest $\frac{1}{1}$ inch below. Where appropriate, $\frac{1}{8}$ of an inch or $\$$ pound was added to the figures in the analyses. Children were weighed with their clothes on but without shoes, and samples of clothing were weighed so that nude weights could be estimated. 
All measurements were made by one observer. The ages were obtained from the school registers.

\section{RESULTS}

Mean heights and mean estimated nude weights of schoolboys and schoolgirls in the five divisions of Barbados were compared by yearly age groups, but no material differences were found between the results from the separate areas. These tables may be obtained from the authors. Means, standard deviations, and the 10th, 25th, 50th, 75th, and 90th percentiles are given for heights and weights of boys and girls from all parts of the island in Table $I$.

Figs 2 and 3 (overleaf) compare the mean heights and weights of schoolboys and girls in Barbados with those of Jamaica in 1964 (Ashcroft and Lovell, 1966a), St. Kitts in 1964 (Ashcroft and others, 1965), London in 1905-12 (Menzies, 1940), and London in 1959 (Scott, 1961). The figures have been plotted at the mid-points of yearly age intervals and the London data have been reduced by weight of clothing where necessary.

Table II shows the mean heights and weights of children who attended schools where the provision of free meals had been introduced before our survey was undertaken.

\section{Discussion}

The height and weight curves of school children have been shown to be representative of all children of corresponding age in the community in Jamaica (Ashcroft and Lovell, 1966b). This is likely to be true also of Barbados, where school attendance is at

TABLE I

HEIGHTS AND ESTIMATED NUDE WEIGHTS OF SCHOOL CHILDREN IN BARBADOS, 1965

\begin{tabular}{|c|c|c|c|c|c|c|c|c|c|c|c|c|c|c|c|c|}
\hline \multirow{3}{*}{ Sex } & \multirow{3}{*}{$\begin{array}{l}\text { Age } \\
\text { (yrs) }\end{array}$} & \multirow{3}{*}{$\begin{array}{l}\text { No. of } \\
\text { Children }\end{array}$} & \multicolumn{7}{|c|}{ Height (in.) } & \multicolumn{7}{|c|}{ Weight (lb.) } \\
\hline & & & \multirow{2}{*}{ Mean } & \multirow{2}{*}{ S.D. } & \multicolumn{5}{|c|}{ Percentiles } & \multirow{2}{*}{ Mean } & \multirow{2}{*}{ S.D. } & \multicolumn{5}{|c|}{ Percentiles } \\
\hline & & & & & 10th & 25th & 50th & 75th & 90th & & & 10th & 25 th & 50 th & 75th & 90 th \\
\hline Boys & $\begin{array}{l}5- \\
6- \\
7= \\
8= \\
9= \\
10= \\
11= \\
12= \\
13= \\
14-(15)\end{array}$ & $\begin{array}{l}486 \\
492 \\
498 \\
488 \\
471 \\
463 \\
500 \\
500 \\
466 \\
300\end{array}$ & $\begin{array}{l}43 \cdot 2 \\
45 \cdot 4 \\
47 \cdot 8 \\
49 \cdot 6 \\
51 \cdot 3 \\
53 \cdot 2 \\
55 \cdot 1 \\
56 \cdot 7 \\
58 \cdot 7 \\
60 \cdot 9\end{array}$ & $\begin{array}{l}2 \cdot 0 \\
2 \cdot 1 \\
2 \cdot 2 \\
2 \cdot 2 \\
2 \cdot 2 \\
2 \cdot 4 \\
2 \cdot 4 \\
2 \cdot 5 \\
2 \cdot 9 \\
3 \cdot 2\end{array}$ & $\begin{array}{l}40 \cdot 7 \\
42 \cdot 8 \\
45 \cdot 2 \\
46 \cdot 9 \\
48 \cdot 7 \\
50 \cdot 2 \\
52 \cdot 1 \\
53 \cdot 6 \\
55 \cdot 1 \\
56 \cdot 6\end{array}$ & $\begin{array}{l}42 \cdot 0 \\
44 \cdot 1 \\
46 \cdot 5 \\
48 \cdot 1 \\
50 \cdot 0 \\
51 \cdot 7 \\
53 \cdot 6 \\
55 \cdot 0 \\
56 \cdot 8 \\
58 \cdot 9\end{array}$ & $\begin{array}{l}43 \cdot 1 \\
45 \cdot 5 \\
47 \cdot 8 \\
49 \cdot 7 \\
51 \cdot 2 \\
53 \cdot 1 \\
55 \cdot 1 \\
56 \cdot 7 \\
58 \cdot 5 \\
61 \cdot 0\end{array}$ & $\begin{array}{l}44 \cdot 7 \\
46 \cdot 9 \\
49 \cdot 1 \\
51 \cdot 1 \\
52 \cdot 9 \\
54 \cdot 7 \\
56 \cdot 7 \\
58 \cdot 6 \\
60 \cdot 6 \\
62 \cdot 8\end{array}$ & $\begin{array}{l}45 \cdot 7 \\
48 \cdot 1 \\
50 \cdot 2 \\
52 \cdot 2 \\
54 \cdot 2 \\
56 \cdot 1 \\
58 \cdot 1 \\
60 \cdot 0 \\
62 \cdot 5 \\
65 \cdot 1\end{array}$ & $\begin{array}{l}39 \cdot 5 \\
43 \cdot 5 \\
48 \cdot 6 \\
53 \cdot 6 \\
57 \cdot 8 \\
63 \cdot 7 \\
69 \cdot 9 \\
76 \cdot 0 \\
83.9 \\
94 \cdot 5\end{array}$ & $\begin{array}{r}4 \cdot 8 \\
5 \cdot 3 \\
5 \cdot 8 \\
7 \cdot 1 \\
7 \cdot 8 \\
8 \cdot 3 \\
9 \cdot 5 \\
11 \cdot 5 \\
13 \cdot 9 \\
16 \cdot 5\end{array}$ & $\begin{array}{l}33 \cdot 4 \\
37 \cdot 0 \\
42 \cdot 0 \\
45 \cdot 5 \\
49 \cdot 2 \\
54 \cdot 3 \\
59 \cdot 1 \\
62 \cdot 8 \\
68 \cdot 0 \\
74 \cdot 7\end{array}$ & $\begin{array}{l}36 \cdot 2 \\
40 \cdot 0 \\
44 \cdot 7 \\
48 \cdot 5 \\
52 \cdot 8 \\
57 \cdot 9 \\
63 \cdot 1 \\
68 \cdot 4 \\
73 \cdot 9 \\
82 \cdot 4\end{array}$ & $\begin{array}{l}39 \cdot 5 \\
43 \cdot 5 \\
48 \cdot 1 \\
53 \cdot 0 \\
57 \cdot 1 \\
62 \cdot 9 \\
69 \cdot 2 \\
74 \cdot 5 \\
82 \cdot 1 \\
93 \cdot 1\end{array}$ & $\begin{array}{r}42 \cdot 7 \\
46 \cdot 7 \\
52 \cdot 0 \\
57 \cdot 8 \\
62 \cdot 2 \\
68 \cdot 8 \\
75 \cdot 6 \\
82 \cdot 0 \\
91 \cdot 8 \\
104 \cdot 2\end{array}$ & $\begin{array}{r}45 \cdot 7 \\
50 \cdot 0 \\
55 \cdot 7 \\
62 \cdot 2 \\
66 \cdot 5 \\
74 \cdot 1 \\
81 \cdot 6 \\
89 \cdot 3 \\
103 \cdot 0 \\
116 \cdot 4\end{array}$ \\
\hline Girls & $\begin{array}{l}5= \\
6= \\
7= \\
8= \\
9= \\
10= \\
11= \\
12= \\
13= \\
14-(15)\end{array}$ & $\begin{array}{l}478 \\
477 \\
485 \\
489 \\
496 \\
500 \\
509 \\
484 \\
396 \\
254\end{array}$ & $\begin{array}{l}43 \cdot 1 \\
45 \cdot 4 \\
47 \cdot 4 \\
49 \cdot 6 \\
51 \cdot 8 \\
53 \cdot 5 \\
56 \cdot 2 \\
58 \cdot 1 \\
59 \cdot 9 \\
61 \cdot 3\end{array}$ & $\begin{array}{l}1 \cdot 8 \\
2 \cdot 0 \\
2 \cdot 0 \\
2 \cdot 3 \\
2 \cdot 2 \\
2 \cdot 4 \\
2 \cdot 8 \\
2 \cdot 9 \\
2 \cdot 8 \\
2 \cdot 6\end{array}$ & $\begin{array}{l}40.9 \\
42.7 \\
45.0 \\
47.0 \\
49 \cdot 1 \\
50.6 \\
52.6 \\
54 \cdot 2 \\
56.6 \\
58 \cdot 2\end{array}$ & $\begin{array}{l}41 \cdot 9 \\
44 \cdot 0 \\
46 \cdot 1 \\
48 \cdot 1 \\
50 \cdot 2 \\
52 \cdot 0 \\
54 \cdot 2 \\
56 \cdot 1 \\
58 \cdot 1 \\
59 \cdot 9\end{array}$ & $\begin{array}{l}43 \cdot 0 \\
45 \cdot 5 \\
47 \cdot 5 \\
49 \cdot 5 \\
51 \cdot 7 \\
53 \cdot 6 \\
56 \cdot 1 \\
58 \cdot 1 \\
59 \cdot 9 \\
61 \cdot 2\end{array}$ & $\begin{array}{l}44 \cdot 2 \\
46 \cdot 8 \\
48 \cdot 8 \\
51 \cdot 0 \\
53 \cdot 1 \\
55 \cdot 1 \\
58 \cdot 1 \\
60 \cdot 1 \\
61 \cdot 8 \\
63 \cdot 1\end{array}$ & $\begin{array}{l}45 \cdot 2 \\
48 \cdot 0 \\
49 \cdot 9 \\
52 \cdot 6 \\
54 \cdot 2 \\
56 \cdot 7 \\
60 \cdot 1 \\
61 \cdot 7 \\
63 \cdot 2 \\
64 \cdot 6\end{array}$ & $\begin{array}{r}38 \cdot 6 \\
42 \cdot 8 \\
46 \cdot 9 \\
53 \cdot 4 \\
58 \cdot 6 \\
64 \cdot 4 \\
75 \cdot 6 \\
83 \cdot 3 \\
93 \cdot 7 \\
100 \cdot 8\end{array}$ & $\begin{array}{r}4 \cdot 6 \\
5 \cdot 8 \\
6 \cdot 0 \\
8 \cdot 8 \\
8 \cdot 3 \\
10 \cdot 5 \\
14 \cdot 7 \\
15 \cdot 3 \\
16 \cdot 1 \\
15 \cdot 9\end{array}$ & $\begin{array}{l}32 \cdot 9 \\
35 \cdot 6 \\
39 \cdot 5 \\
44 \cdot 1 \\
49 \cdot 4 \\
52 \cdot 7 \\
60 \cdot 1 \\
65 \cdot 0 \\
74 \cdot 1 \\
81 \cdot 0\end{array}$ & $\begin{array}{l}35 \cdot 4 \\
38 \cdot 8 \\
43 \cdot 2 \\
47 \cdot 6 \\
53 \cdot 1 \\
57 \cdot 2 \\
65 \cdot 9 \\
72 \cdot 9 \\
82 \cdot 1 \\
90 \cdot 2\end{array}$ & $\begin{array}{r}38 \cdot 3 \\
42 \cdot 5 \\
46 \cdot 5 \\
52 \cdot 2 \\
57 \cdot 6 \\
63 \cdot 1 \\
72 \cdot 8 \\
81 \cdot 4 \\
92 \cdot 8 \\
100 \cdot 9\end{array}$ & $\begin{array}{r}41 \cdot 5 \\
46 \cdot 0 \\
50 \cdot 3 \\
57 \cdot 8 \\
63 \cdot 3 \\
69 \cdot 9 \\
84 \cdot 0 \\
92 \cdot 8 \\
103 \cdot 1 \\
111 \cdot 1\end{array}$ & $\begin{array}{r}44 \cdot 6 \\
49 \cdot 3 \\
53 \cdot 5 \\
63 \cdot 6 \\
69 \cdot 2 \\
78 \cdot 3 \\
92 \cdot 5 \\
101 \cdot 8 \\
115 \cdot 1 \\
122 \cdot 1\end{array}$ \\
\hline
\end{tabular}

TABLE II

MEAN HEIGHTS (IN.) AND ESTIMATED NUDE WEIGHTS (LB.) OF BARBADIAN SCHOOL CHILDREN RECEIVING FREE SCHOOL MEALS AT THE TIME OF THE SURVEY, 1965

\begin{tabular}{|c|c|c|c|c|c|c|}
\hline \multirow{2}{*}{$\begin{array}{l}\text { Age } \\
\text { (yrs) }\end{array}$} & \multicolumn{3}{|c|}{ Boys } & \multicolumn{3}{|c|}{ Giris } \\
\hline & No. & Height & Weight & No. & Height & Weight \\
\hline $\begin{array}{l}5= \\
6= \\
7= \\
8= \\
9= \\
11= \\
12= \\
13= \\
14=(15)\end{array}$ & $\begin{array}{l}99 \\
77 \\
84 \\
63 \\
66 \\
67 \\
52 \\
41 \\
27 \\
9\end{array}$ & $\begin{array}{l}43 \cdot 2 \\
45.5 \\
47.9 \\
49.8 \\
51 \cdot 7 \\
52.8 \\
54.8 \\
56.9 \\
59.6 \\
59.3\end{array}$ & $\begin{array}{l}39 \cdot 3 \\
43 \cdot 2 \\
48 \cdot 4 \\
53 \cdot 3 \\
58 \cdot 8 \\
62 \cdot 1 \\
69 \cdot 2 \\
73 \cdot 8 \\
87 \cdot 7 \\
89 \cdot 8\end{array}$ & $\begin{array}{r}121 \\
117 \\
118 \\
116 \\
98 \\
116 \\
42 \\
32 \\
24 \\
4\end{array}$ & $\begin{array}{l}45 \cdot 0 \\
45 \cdot 2 \\
47 \cdot 3 \\
49 \cdot 8 \\
52 \cdot 0 \\
53 \cdot 7 \\
56 \cdot 7 \\
57 \cdot 3 \\
60 \cdot 3 \\
60 \cdot 1\end{array}$ & $\begin{array}{l}38 \cdot 3 \\
42 \cdot 5 \\
46 \cdot 3 \\
54 \cdot 5 \\
59 \cdot 8 \\
64 \cdot 7 \\
76 \cdot 5 \\
78 \cdot 5 \\
91 \cdot 5 \\
93 \cdot 2\end{array}$ \\
\hline
\end{tabular}


least as good and dates of birth as given in school registers appear to be more reliable. The birth certificate is supposed to be shown to the headmaster when the child is first registering at school,

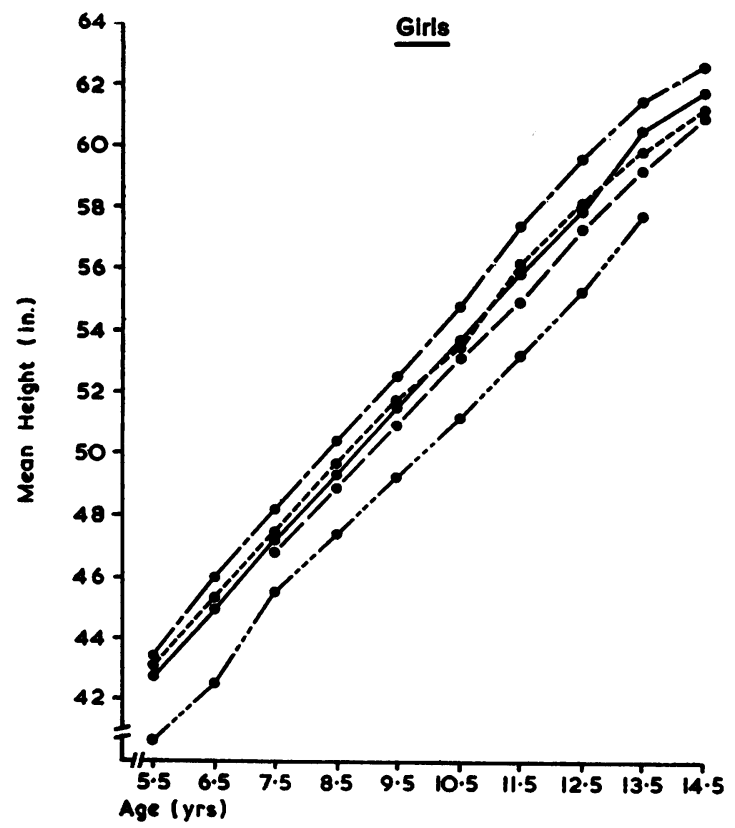

and although it was found that baptismal certificates are often accepted in lieu, dates of births were always obtained from one of these two sources. Representation of the whole island was obtained

Fio. 2.-Mean heights, by age and sex.
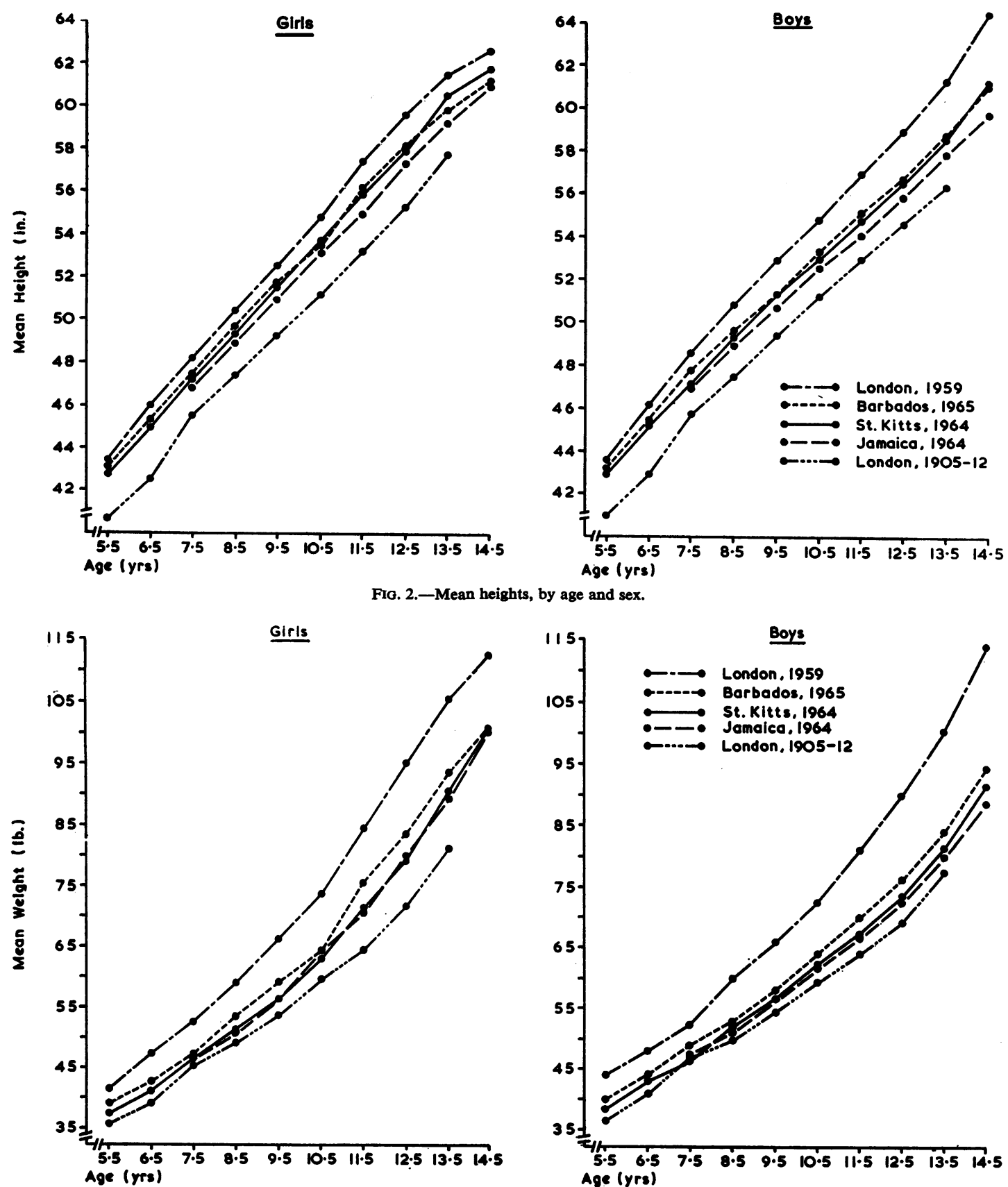

Fio. 3.-Mean woights, by age and sex. 
by dividing it into five geographical areas and by visiting sufficient schools in each area to obtain samples of 100 children in most age groups. The children measured were nearly all of African origin although a few had various degrees of European ancestry.

Barbados is a small island and it was not expected that the size of children would be greatly affected by geographical features, although in Jamaica children living in hilly inland areas have been found to be smaller than those from low-lying coastal and urban areas (Ashcroft and Lovell, 1966a). Measurements made in the five areas were similar and have been combined (Table I) without weighting for different sizes of catchment populations. A statistical comparison of the figures does show that boys in the north and south-east coastal areas are taller than those in the hills and in the centre of the island, and that girls in the north coastal area are taller than those in the centre of the island. However, the differences are small and may be due more to the inclusion of particular schools than to real differences between the areas, since there are greater differences in size between city boys from neighbouring schools than between areas.

Heights and weights of Barbadian children under 7 years of age have been given by Standard (1964). These were collected in 1961 as part of a nutrition survey on "seacoast" and "inland" children and published in 6-month age groups. A graphical comparison of the age range which overlaps with that of the school children in the present study shows that the children in the earlier study were about 1 in. shorter and about $1+$ lb lighter. The numbers reported earlier were not great and the curves obtained were irregular. Differences could be due to differences in technique or in sampling.

Barbadian school children are slightly bigger than school children of the same racial origin in the other Caribbean islands of Jamaica and St. Kitts-NevisAnguilla. Figs 2 and 3 show that school children in St. Kitts, which occupies an intermediate geographical position between Barbados and Jamaica, are bigger than school children in Jamaica and smaller than those in Barbados. This is perhaps a little surprising since Barbados is the most densely populated of these three territories, with 1,400 persons per square mile in contrast to 380 in Jamaica and 570, 360, and 160 per square mile in the three islands of the St. Kitts group. Of the three territories Jamaica has the most diverse agriculture, the others being more heavily dependent upon sugar cane. It is hoped to compare the sizes of infants from these three islands in a later paper.
The Barbadian children have also been compared with children measured in London in 1905-12 and 1959 (Figs 2 and 3). They are bigger than London children born half a century earlier but smaller than their London contemporaries. The secular increase in size of London school children is almost certainly due to improved living standards and it is reasonable to conclude that the general environmental circumstances of school children in Barbados in 1965 were intermediate between those of London children in 1905-12 and in 1959. Although the Barbadian children were of African origin, they are unlikely to differ very much racially from Jamaicans of African origin who have been shown to possess at least the same potentialities for growth as Jamaicans of European origin (Ashcroft and Lovell, 1964; Ashcroft, Heneage, and Lovell, 1966).

A feature of the comparisons with English children is the greater disparity between older Barbadian and London school children of the present day than between those of younger ages. Although our survey was cross-sectional, this is suggestive of a continuing disadvantage which results in a slower rate of growth throughout the growing period; but it could be due to a differential secular trend operating in favour of Barbadian children. No data on adults are available to show whether Barbadians grow for a longer period or attain a smaller stature.

It is also noted that the positions of the Barbadian curves between the pairs of London curves differ for height and weight. Height appears to occupy a better relative position than weight.

The disparities in both heights and weights between Barbadian girls and present-day London girls appear to be less than those between Barbadian and London boys. This has also been noted for school children in St. Kitts (Ashcroft and others, 1965) and Jamaica (Ashcroft and Lovell, 1966a), where differences between Chinese girls and girls of other races were greater than those between Chinese boys and other boys, suggesting the possibility of a racial difference in the relative sizes of the sexes (Ashcroft and others, 1966). On the other hand, there was no indication of this pattern in Chinese children in Hong Kong as measured by Chang, Lee, Low, and Kvan (1963). The cause may be racial or there may be some factor in the environment of the West Indies which favours girls of African and European origin or produces earlier maturation amongst them. For example, the diet of boys may be less adequate than that of girls in relation to requirements, so that not only is growth retarded but potential height is never attained.

At the time of the present survey, free school 
meals had been introduced into only six of the 35 schools investigated. The mean heights and weights of boys and girls from these schools are given in Table II. There was no particular difference in size between these children and those not receiving school meals but, as free school meals were a recent innovation. this was as expected.

Growth curves may well provide a better index of the state of health and nutrition of a community than do brief clinical surveys (Standard, Lovell, and Garrow, 1966). The equivocal signs attributable to malnutrition and ill-health are difficult to classify and to interpret and reproducibility between one observer and another, and between the same observer on different occasions may be low, because unless disease and deficiency are gross, abnormal signs may be minimal.

\section{SUMMARY}

The heights and weights of 9,232 Barbadian school children, aged 5 to 15 years and predominantly of African origin, were measured.

The children were slightly larger than school children in Jamaica and in St. Kitts-Nevis-Anguilla. They were bigger than London children measured in 1905-12 but smaller than London children measured in 1959.

Tables are given which will provide a baseline for future studies of secular change in the growth of school children in Barbados.
The survey was carried out by means of a grant from the West Indian Medical Research (Local Grants) Scheme on the recommendation of the Standing Advisory Committee of Medical Research in the British Caribbean, and supported by assistance through a Milbank Memorial Fund Faculty Fellowship.

We wish to thank field workers Mrs. M. Whitehead and Miss P. Thornhill.

Thanks are also due to the Education Department and the school teachers of the Ministry of Education and the Chief Medical Officer, Government of Barbados, for their help and co-operation.

\section{REFERENCES}

Ashcroft, M. T., Buchanan, I. C., and Lovell, H. G. (1965). J. trop. Med. Hyg., 68, 277.

, Heneage, P., and Lovell, H. G. (1966). Amer. J. Phys. Anthrop., in press.

- and Lovell, H. G. (1964). Trop. geogr. Med., 16, 346. (1966a). J. trop. Pediat., in press. (1966b). W. Indian med. J., 15, 27.

Chang, K. S. F., Lee, M. C. M., Low, W. D., and Kvan, E. (1963). Amer. J. Phys. Anthrop., 21, 497.

Menzies, F. (1940). "Average Heights and Weights of Elementary School Children in the County of London in 1938". London County Council, London.

O'Loughlin, C. (1960). In "Economy of the West Indies", ed. G. E. Cumper. University of the West Indies, Kingston, Jamaica.

Scott, J. A. (1961). "Report on the Heights and Weights (and Other Measurements) of School Pupils in the County of London in 1959". London County Council, London.

Standard, K. L. (1961). W. Indian med. J., 10, 250. (1964), Ibid., 13, 77.

—. Lovell, H. G., and Garrow, J. S. (1966). J. trop. Pediat., in press. 